\title{
趈轉圖形の知覺
}

東京帝大心理營研究室

小林 卓郎

1 圖 2 に示寸樣な種々の圖形を每秒 0.3 迴輔乃至 5 迴轉せしめた場合如何に現象 するかを觀察し，特に逆轉現象に就いて二三の實驗孛行ら。實驗期間は昭和 13 年 6 月 下旬加的 11 月下旬迄。

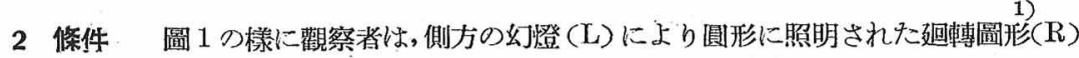
から約 123 粧の所に座して觀察する。使用した圖形は圖 $2 の 9$ 種である。

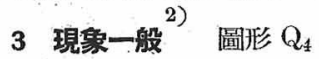
圆 1

に於で觀察された所は次の 通りで女る。圖形情靜止時 には全部が等質的な白い地 に黑い小さい方形が 4 個 對稱に゙並儿でるるといらなだ けで出つて 4 黑方形相互 の間には現象的に別に何等 の關聯もない。然るに僅か 二三回ゆつくり廻轉し始め ると刨座に圖 3 の見方方

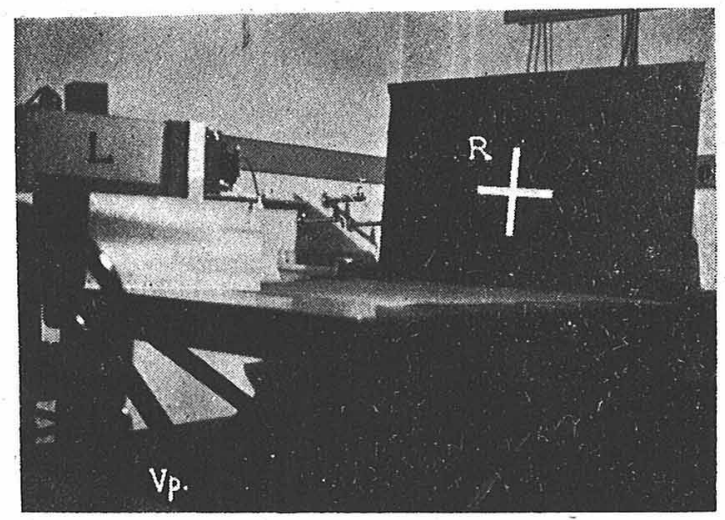
が起る。中央の㵋は慧味がかつた灰色であつて白い地に對して色調を異にし明確な境界を 有する。黑い 4 個の方形はこの圓によつて互に離れることの出來關係に結びつけられ る。 0.3 前後で何上りも先に强制的に現れる見え方であるが，一寸迴轉數が堆寸と中央の 圓形は角つ丸くとれた方形になる。色調つ戀化は前こ同樣でせる。墳員は起ることなく， 4 個性は本資的でむる。奧行む生じない。これを見え方 „1”と名付けて括く。(圖 4)

0.6 前後で新しい見え方が二つ生ずる。十字形に上から心もち離れて丸い純白紙で蓋が してあつて, その背後を十字形が何の障害も受けずに迴轉してるるといら碓然たる現象を

1) 趈轉方向壮總て時計の針と同方向。

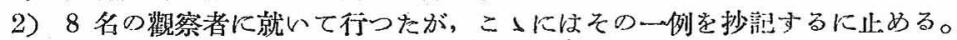

3) 以下每秒の迴轉數 (無名数) ※以て迴轉速度を表し文「每秒の迴轉數」を「趈轉數」 と略記する。 
具いてるる(圖 ら)。見え方 „1”で起らなかつた增員が同じ迴轉數で暗示的に起る。これ を見え方 ,2”と名 付けて括く。又白 黑の縞或は斑のあ る輪が廻轉する樣 に見えることがあ る(圖 6)。中央の 白圓については見 え方, 1”の樣な色 調の變化はなく， 或はあつて子極く 僅かで明瞭でない 事乃゙强く感ぜられ る。この圓は見え

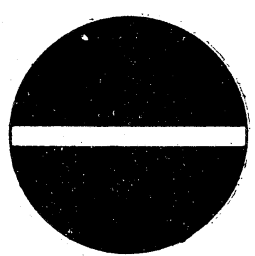

圖形 $\mathrm{A}_{2}$

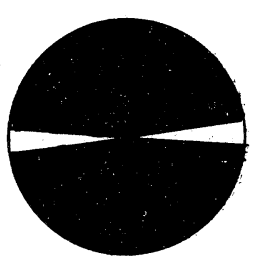

圖形 $\mathrm{B}_{2}$

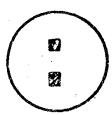

圖形 $\mathrm{Q}_{2}$

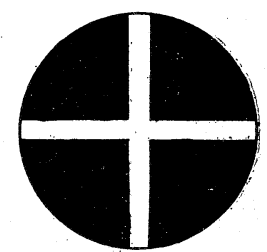

圖形 $\mathrm{A}_{4}$

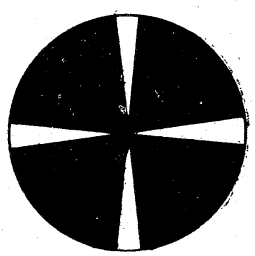

圆形 $\mathrm{B}_{4}$

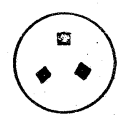

周形 $\mathrm{Q}_{3}$

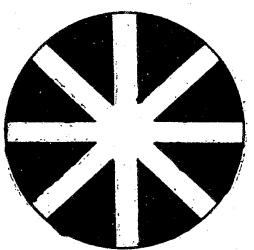

嫡形 $\mathrm{A}_{8}$

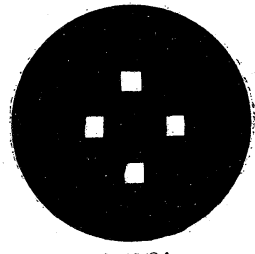

圖形 $\mathrm{Q}^{\prime}$

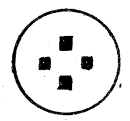

圖形 $Q_{-}$ が,こっでは全く
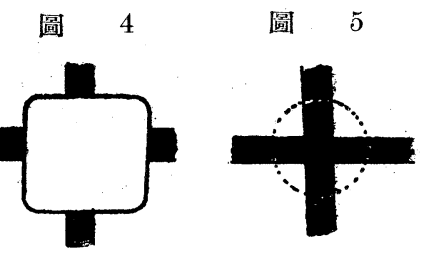

圆 6

の地になつてる る。又見文方，2” と違つて奧行が少 ともなく且つ同じ 速度で墰員もしな

い。この環現象を見え方, „3”と名付けて扔く。

圖形 $\mathrm{Q}^{\prime}{ }_{4}$ であると見え方, „1”では矢張り角の丸くと礼た灰色の方形にその附屬物とし て 4 個の白い方形がついてみる。 圖 7

見え方,2”で白い輸に跨つた 4 個 の濃い屧形が圖となつて迴轉を擔 ふ。䝬するときは紫の扇形は觜同 じ栐に尖り等間隔である。中心部 程濃く奧にはいつてるる。その迴轉 は錐でもみ込む樣な感じがする（圖
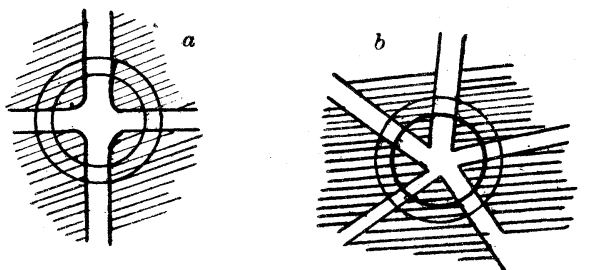

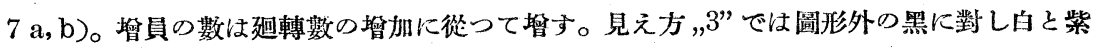


の輪である。白といっても電燈によつて照明され黄味を帶びてるるからその補色なる紫色 が輪の白色ならざる部分を埋めたのである。

(以下再び圖形 $\mathrm{Q}_{4}$ に就て) 0.6 で増員してるるとき,意志的に圖形を 4 個の互に獨立し た黑い力形とみなほすと增員は㨁ちに中絕する。併し4個を互に全く關係のないばらばら のものと見やうとする努力は無效であつて中央の圓形を關心の中心加ら外らすことは僢間 的にしか成功しない。先づこの場合は見え方,””の一變形であらち。なほ見え方,2”によ れば圖形的に明確な輪廓線を有して迴轉の仕方も滑かであつた 4 黑方；圖 8 形が，この見え方では運動方向の前緣側面でぼやけ且つ動き方がギク シャク寸る樣になる(圖 8)。郎ち走り方に節が出來, 又各小圖形は公轉 に件つて連續的に自轉することがない(圖 9)。0.6では ,1”, „2”, ,3” 三樣の見え方が交替して現れる。,2”墰員といつてす次に述べる程

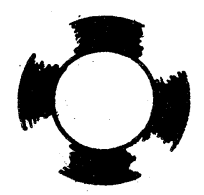

圖 9

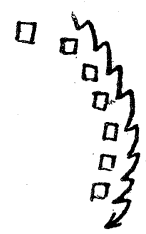

圖 10

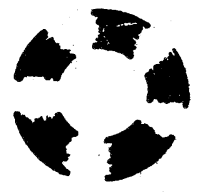

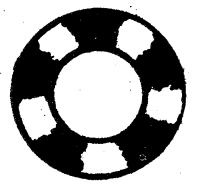

明膫なものではない。 0.8 では見え方 ,1”は 殆ど出なくなり，且つ見 之方,,3”でも時に明瞭に 5 個に增員する。その場 合5個の黑形は同形, 同强度で相互間隔は相等しく總ての點で甲乙がない。

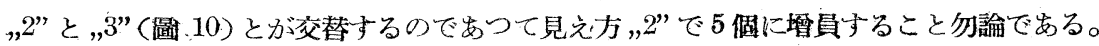
1.0 に至ると5個への增員は明確となると同時に迴轉のビクッキが激しい。見え方 „3” では動搂だけがあつて迴轉方向つなくなることがある。直ちに消える現象であるが下に述 ベる現象的逆轉の前觸れ段階であるやらでもある。

又新たな見え方として見え方，3”の輸の半分乃至大部分が真黑になることがある（圖

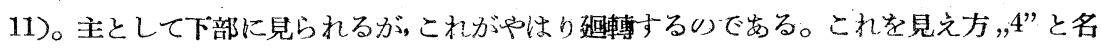
村けて招く。

以上は總て圖形全般を萬遍なく一樣に見渡さ 万と努力した場合で女るが（凝視默刺战なき䉆 實際にどこを見てるるか(生不明である)次に見 之方, ,3”で四つの黑方形の中 1 個を䅐線で追

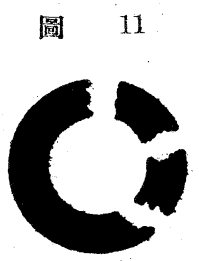
圖 12 跡すると、それだけは輪廊力淜膫な方形となり

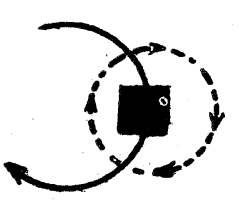

且黑色である。又この圖形に限つて公轉に際し 1 回餘分に 自轉する。物理的にか〉る事 態は山り得ぬと考へて特にその點に留意して追跡するとその矛盾現象はなくなるが，しか

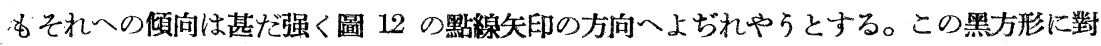


して他の黑方形は比較になら程ぼやけてるるが，その小前省に近いもの程黑く輪廓もや

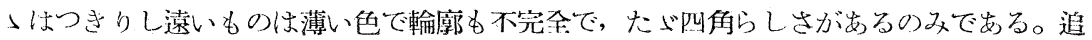

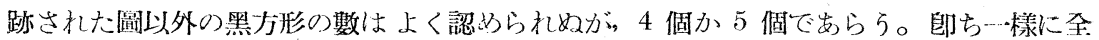
般を見渡した場合上りも增員した數は多い。その場合各訚形間の間隔は追跡された圖形に 近い程廣い。

この追跡を…迴轉續けて急に中心に斍線を移与と見えオ „3” は笑如 „2”に代り同時 に逆轉老生ずる。詳しく記述することは困難な現象であるが，埇13 圆 13 の如くでをららか。正轉逆轉が繼起的に連續して起り, 逆轉の力が 速度大でをるらしい。同時にそれと別個に正迴轉が連續的に起つて

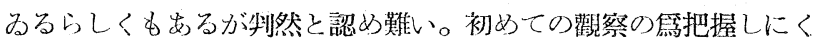

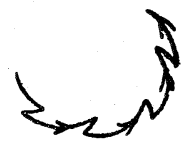
かつた。この逆迴輔は $360^{\circ}$ の一周もしない位で間もなく正迴轉の見え方，3”に鼠り，

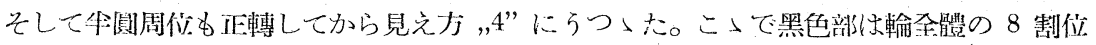

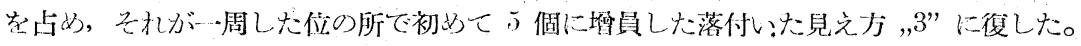

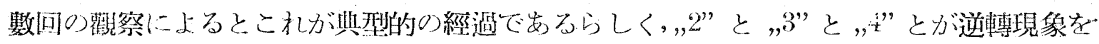
㑕んで交筸与る。逆轉の前後では常に見えすが翼つた。

見え方, „2”は次第に起りにくななるので女つて,1.2ではなかなか見えず，出てもすぐ見

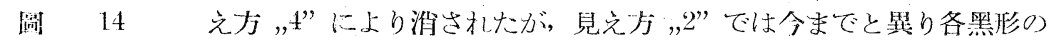

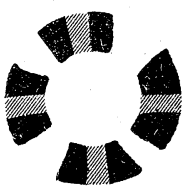
自己分裂が起つ方(圆 14)。二乗の縞になるので女つて,その各ふは连

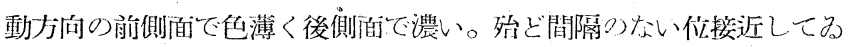
るが，强い照明を與え光じ分離与る。分裂しなものをさ個と數へると 全體で黑形の數は 8 個內外で发的らか。或はメッガーの觀察したへリ ング氏殘像ぶそれであるか子知れない。

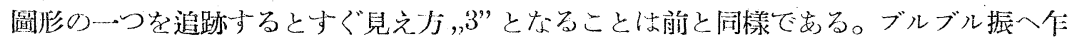
ら廻轉するか澗もなく見え力 „4”に上つて消さ扎更にこの, ,“が分裂してト記の二重縞 の見え方，2”となつたり＼cjkstart爻は,„3”となつたりした。

1.5 となると見え力,2”と,3”とが交筸して起り共に 10 個內外に㻼員してるる。その 甬形は著しくぼけてるる。且見え广，3”の場合これまでも迴轉數の增すに從つて次第に 現れた奧行効果が㙷著となり，地である內外の測はずつと手前にせる。即ち環狀に切り拢， いた空のずつと後で圆形が迴轉してるるといら印象である。文先に述べな樣な方向がなく て動摇だけが起ることがしばしばもつた。これを見え方,っ”と名付けて物く。假現運動の 同じ場所への繼洔露出，持續觀察のやらに內部運動が激しい。そして正轉も逆轉もないの， で岕る。 
なほ同じ見え方,3”で女りながら，廻轉のビクッキが激しい時增員は小で女り，圓滑に 廻轉する時澤山に增すことに氣付いた。逆轉現象は前上りも見易く增員した圖形の一つが 直ぐ後のに極くゆつくり飛んで逆戻りするのである。そして而もそれと同時に正廻轉が續 けられた。この逆轉は暼員した澤山の黑圖形の中の一部分に就いて見られ１/4圆周优迴つ て見え方 „4”に移行した。

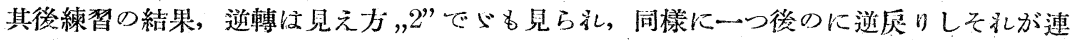
續的に起つた, 圖形 $Q^{\prime \prime}$ では 2.0 ゲ 10 乃至 20 湖に增員し, こいて正轉する環の上に

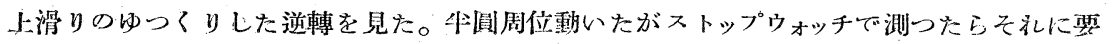
ナる時間は 3 秒であつた。この逆轉け正轉の上を滑るといふはつきりした現象のある點, ギクシャクせず滑らな點等々で體驗的に上述のパタパタ逆轉とは異種と思汅る。

1.8 から 2.0 で增員は更に旺んで 20 個內外と思はれるが，到底算へられない。見え方 „3”だけ㚣つて外の見え方は起らず，たら゙黑白の縞の岕る輪が見之るばかりでせる。見え

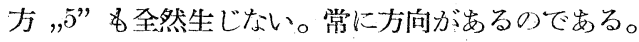

2.3, 2.6 では本質的に變化なく，たよ゙斑が次第に密になり，3.0に至つて融合に近くなる が，まだ灰色の輪の中に斑があり，動摇があり，縞の痕跡を殘す。

3.6 で等質的な灰色の輪に融合した。融合に近づくに從ひ一旦顯著ですつた奥行效果は ぞんどん減じてゆき，最後の段階では殆んどない。即ち灰色の輪が版地のトにぴつたり 㙋りついてみる。

4 逆轉現象迴轉圖形の知覺中顯著な現象は逆轉現象である。今觀察者 $\mathrm{K}$ が圖形 $\mathrm{A}_{4}$ についで觀察しな所によると次の通りである。逆轉はパタッ, パタッ又はパラッ, パラッと いら感じで正轉の樣に滑らかでない。一ツの棒が正轉に於ける後方の棒に飛び移る樣に思 はれる。その飛び移る中間には圖があるの为ないのかわからない。この樣な連動が後方八 後方へと連續した時上述のパタッ，パタッといふ逆轉をする。かりる逆轉を「刻又岁る逆 轉」と名付ける。

か〉る現象は何人にも生ずることは數名の觀察者に上つて確められたが，その起る程 度は觀察者, 圖形の種類, 趣轉數等によつて異る。ゲールケとラウも云つてるる通り初め ての觀察者は多くの場合逆轉現象を全く認めない。この點に關しては諳しい記錄をとらな かつたが，觀察者 Y は圖形 $A_{4}$ に於ける初めての觀察の際 0.5 より 4.0 までの間(約 2 時間正味觀察時間約 1 時間) 逆轉は全く認めず，唯 1.0 に於てほんの…可戻つた樣だと 言つてるるに過ぎない。然し乍ら香に角觀察時間に長短はせつても逐には何人も逆轉を認 め, 通常は 30 分以內の觀察で生起ずる。併しながら初めから明膫な逆轉が見られるので はなく必ず一定の段階を經る樣である。即ち前述のビクッキとかギクシャクするとかいふれ 
のがそれで女る。又或觀察者は一僢ガクンと停止する事が岁ると述べてるる。(目ばたさ を与ればー一瞬圖形の輪廓は明䐲になり，而もガクンと停此し或は速度の變化を認めるが上

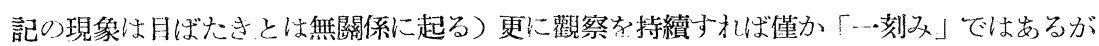
確かに逆轉したといふ印象を受ける。而して逐にはかつる「刻み」が連續して起る樣にな る。逆轉生起つ程度は觀察然, 廻轉數及圖形の種類並に練丕によつて相違与るが圖形 $\mathrm{A}_{4}$ に於ける觀察者 $\mathrm{K}$ の報告は次の通りで女る。

0.3

$0 . \overline{6}$

1.1

1.6

2.0 以上:
1 刻及乃至 3 刻及, 時々起る。

2 刻及乃集 8 刻久, しばしば起る。

4 刻夕乃至 15 刻夕, 極めて頻繁に起る。

時にガクンと停止する樣な事が安る。

上記の通り䞤轉數に上つてかなり明確な段階の岁る事は他の憼察者にも認められる事 で，例へ欟察者Ｕは 1.0 で「逆轉特に著しく」1.4で「餘り起らず」2.0で「全く認 めない」。その中で 2.0 以上で逆轉を認めない事は總ての觀察者に共通で岁る。では逆轉の 起る下限泃轉數 (最低速度) が发るかとい心に觀察者 H は 0.3 , 觀察者 Y は 0.3 乃至 0.5 に於て全然逆轉を認めて居らないが，觀察者 Kは 0.3 に於て子極めて明膫に逆轉を認め てるる點からすれば極めて低速度に於ても逆轉は起り得ると言は䄈ばならぬ。

次に他の圖形の場合とを簡單に比較してみるに, 圖形 $\mathrm{A}_{n}, \mathrm{~B}_{2}$ では 1.5 に於てもよく起 り, 更に2.0に於ても時々起る。圖形 $\mathrm{B}_{4}, \mathrm{Q}_{4}$ では $\mathrm{A}_{4}$ の場合とほぶ同樣でせる。侀し乍 ら圖形 $\mathrm{A}_{8}$ では 0.4 で「餘り起らず」, 0.6 では「僅かに一度圆形 $\mathrm{A}_{4}(0.6)$ に於ける位の上 い逆轉圭見た」に過ぎない。

此の項の始めに飛び移るといふことを述べたが，「一飛び毁ち「1 刻み」の距離はどの位

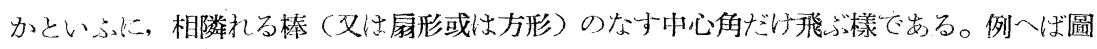
形 $A_{4}(0.3)$ (現象的には 4 本の棒者見てるるる時) では $90^{\circ}$, 圆形 $A_{8}(0.2)$ (現像的には 8 本 の棒な2てる る時) では $45^{\circ}$, 圖形 $\left(Q_{4}(1.0)\right.$ (璔員して現象的には 8 個內外の方形を認め てるる時) では約 $45^{\circ}$ 位逆轉与る。

5 凝視點を置いた場合上沭の雚察では視方向は別段限定しなからた少，今度は 3

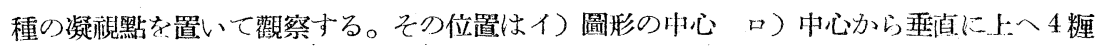
の所 八) 圖形の周邊部 の 3 種で, 圖形は $\mathrm{A}_{4}$ 及 $\mathrm{Q}_{4}^{\prime}$ の 2 種, 廻轉數は $0.3,0.9,2.0$ の 3 種に限つた。

1) 觀祭者 5 名 
1) 中心凝視 3 で述べた諸現象の生起することは變りないが，更に圖形全體が中心に 於て點對㮮的だといぶ印象が極めて强い。逆轉の生起も亦何ら變らず, 同程度に現象する。

2) 中間㠜視 圖形中心點對棦性が幾分失はれ, 例へば圖形 $\mathrm{A}_{4}(0.3)$ に於て「迴轉軸を 中心に十字形が廻つてるることは.中央視の場合と同じだ 圖 15 が，棒の間隔が一定ならず，直交してるる 2 本の棒が，ぐ にゃぐにゃ注んの僅かしなひながら迴つてるる。文 2.0 で は凝視點から上の部分分瀜合してるる。更に對筝性の低下 は奧行效果にも顯れてるる (圖 15, 縱斷面, 矢印は視方

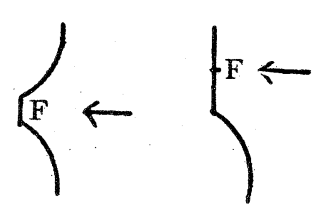
向)。或は又圖形 $\mathrm{Q}_{4}^{\prime}$ では凝視點近くを通過する方形の方が他の方形に比して速度大でせ る。逆轉も亦前と同程度出現するがその際の圖形の對䊈性は幾分失はれてるる。

3) 周邊凝視 先づ圖形 $A_{4}$ についてタるに

0.3 : 蘚明な輪廓線は少しも認められず四っの白いものが動いてるる事はわかるが, 廻轉 の軸（中心）は見當が付かぬ。中間凝視で見られた對䄳性の歪みが一そらひどく，凝視點 を圖（白色のぼんやりしたもの）が左から右一水本方向に通過するといら感じが强い。時 に圖形全體を把握しらることも岁るが，その際には上向きの棒だけが孤立し他の三つは相 互に接近してイの樣にみえる。逆轉は殆ど認めなかつた。

0.9 ：中心，中間凝親より一そら複雜な形態變化を來し表現困難である。今度は逆轉が 比輘的頻繁に起つたが，その際圖形全體が極めて不規則に速く動摇した。此は正轉の際に は2られない。

2.0 : 凝視點を中心として描いた小圓內の部分だけがよく融合してるる。

次に圖形 $\mathrm{Q}^{\prime}{ }_{4}$ につてみるに

$0.3: 4$ 個の方形の見え方は前 (中心, 中間凝視) とは全く異り何れも添けて, 唯凝視點 圖 16 に近いものが幾分はつきりしてをり, 圖形の中心を軸として迴轉し

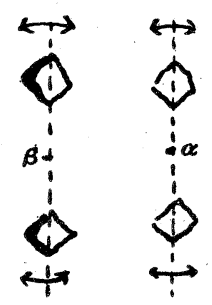
てるることはわかるが，軸の動摇することが女る。(この點は $\mathrm{A}_{4}(0.3)$ に於て廻轉軸のわからなかつたのと異る。) 又 4 個の方形が圓形に 配置されてるるといふよりは圖 16 に於て點線で結んだ二列に並ん でるるといふ感じが强く, 時に逆轉ともビ 第 17 圆 クッキとむいへる樣な動きが見られる。そ の動きは $\alpha, \beta$ を中心にして左右に動く樣

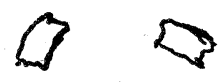

である。

0.9 : 中心, (万至中間) 凝視では 4 個の方形が同じ浿軌道に正 しくのつて迴つてるたが，今度は圆 17 の樣に個々の方形が振れ

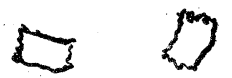


てるる。而してその各々が描く軌道が一致してるる事もむり，或は異つてみる事も岕る。

又圖形 $A_{4}$ 周邊凝視で見た樣な圖形の中心が複雜不規則に動摇与る逆轉をみる。その時 の感じは白いぼけた小片（4 個の方形）が自轉しつ〉投げ上げられ落下してゆくといら風 で，丁度小供がやる手玉遊びの時の手玉の運動の樣で女る。4 個の小片の運動軌道は一致 してるるといふよりは，個々別々に大凡そ同じ位の大さで而も多少位置ぶずれてみるらし い。刻久數は 8 內外のものが最も長かつた。

2.0 : 圖 18 の樣に內部が斑で,ゆがんけ環に見える。環の上方部は下方部に比し斑が密 であるが，中間凝視 2.0 の時の樣に融合するに至らない。又周邊凝 圖 18 視 0.9 の時の樣に斑が振れてるるらしくす女るが左程明瞭でない。 他の圖形, 凝視位置の場合に於けると同樣 2.0 では逆轉は全くみ られない。

\section{6 逆轉現象の起る時間經過逆轉の刻久荅せて電鍵を押}

\begin{tabular}{|c|c|c|c|c|}
\hline 觀察者 & 罳形 & 画䡛數 & 觀察時闍 & 總延轉數 \\
\hline \multirow{4}{*}{$\mathrm{K}$} & $\mathrm{A}_{4}$ & 0.33 & 5 分 24 秒 & 109 \\
\hline & $\mathrm{A}_{4}$ & 0.6 & 6 分 0 秒 & 216 \\
\hline & $\mathrm{A}_{4} *$ & 1.1 & 5 分 28 秒 & 374 \\
\hline & $\mathrm{A}_{4}$ & 1.3 & 7分 & 547 \\
\hline $\mathrm{s}$ & $\mathrm{A}_{4}$ & 0.8 & 4分57秒 & 247 \\
\hline $\mathrm{K}$ & $\mathrm{Q}_{4}^{\prime}$ & 0.7 & 5分17秒 & 223 \\
\hline $\mathrm{H}$ & $\mathrm{Q}^{\prime}{ }_{4}$ & 1.1 & 5 分 32 秒 & 379 \\
\hline
\end{tabular}

し，逆轉の時間的經過をカイモグラフにとつてみ た。觀察者, 使用圖形, 廻轉數, 觀察持續時間は 表 1 の通り。(表中*を例示すれば圖 19 の通り)

1) 頻度々持續時間：先づ第一に篓付く點は觀 察の初期に於て逆轉現象の起りにくい事で女る。 觀察者Kについてみるに

\section{$\mathrm{A}_{4}(0.33)$ では初め 16 秒間は變化なく（逆轉そ} 圖 19

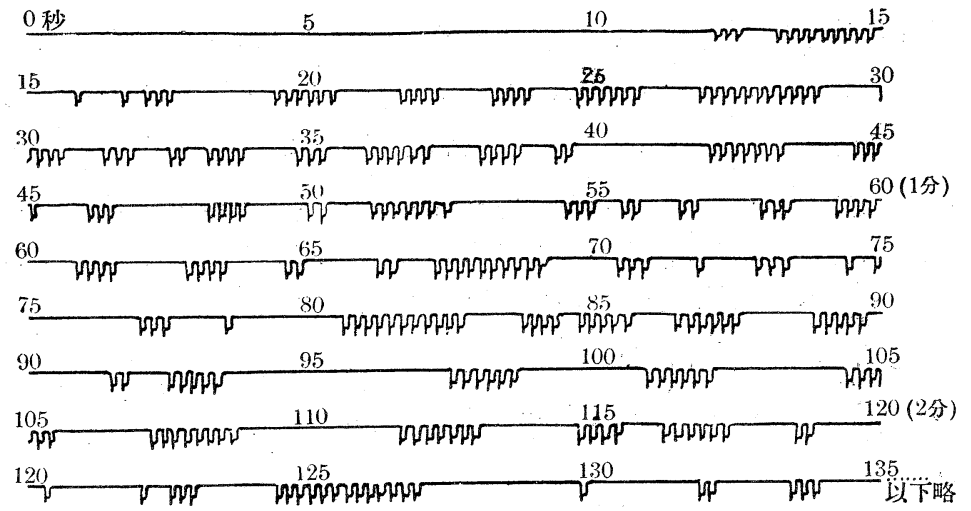

1) 觀察者 4 名 
の他の現象變化), その後 45 秒間には連續した刻みなく, 1 回だけのものが 28 度起り, 次で 3 刻及の逆轉を发てるる。

$\mathrm{A}_{4}(0$. が では初めより 19 秒つ間に 1 刻みのものが 7 度起り, 次で 5 刻みのものをみ た。

$\mathrm{A}_{4}(1.1)$ では初め 12 秒間にはなく以後頻りに起る。

$\mathrm{A}_{4}(1.3)$ では初め 22 秒間にはなく以後頻りに起る。

$\mathrm{Q}_{4}^{\prime}(0.7)$ では初め 5 秒間にはなく後 9 秒間に 1 刻又のもの 6 度起り,次で 3 刻及の ものをみる。

、記の樣に初めて逆轉か起るまでの時間の絕對值は區々であるが，それ以後に於いては それ程逆轉の起らぬ狀態を持續することは全くない。

次に 1 回の持續觀察中逆轉

の生起した時間を見ると表II

の通りである。

上記の結果上りすると廻轉

數と頻度との間にはかなり密

接な關係がある樣に思はれ

る。即ち $0.3,0.6,1.1$ と廻轉

\begin{tabular}{|c|c|c|c|c|c|c|}
\hline 觀繁著 & 圆形 & 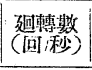 & \begin{tabular}{|c|} 
欟繁時間 \\
(秒)
\end{tabular} & 到及數 & 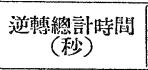 & $\begin{array}{l}\text { 朔轉時閏 } \\
\text { 觀察時間\% }\end{array}$ \\
\hline K & $\mathrm{A}_{4}$ & 0.3 & 324 & 107 & 27 & 8.3 \\
\hline $\mathrm{K}$ & $\mathrm{A}_{4}$ & 0.6 & 360 & 416 & 95 & 26.4 \\
\hline K & $Q_{4}^{\prime}$ & 0.7 & 317 & 390 & 71 & 22.4 \\
\hline K & $\mathrm{A}_{4}$ & 1.1 & 328 & 590 & 107 & 32.6 \\
\hline $\mathrm{K}$ & $\mathrm{A}_{4}$ & 1.3 & 420 & 663 & 126 & 30.0 \\
\hline $\mathrm{s}$ & $\mathrm{A}_{4}$ & 0.8 & 297 & 192 & 48 & 16.0 \\
\hline $\mathrm{H}$ & $Q^{\prime}{ }_{4}$ & 1.1 & 332 & 127 & 32 & 9.6 \\
\hline
\end{tabular}

數の增加に伴つて逆轉の 頻度は增加し，1.3になると逆に減少してるる。この點に關して は資料が一例に過ぎぬので決定的には言へぬが, 1.0 前後で最も上、現像し, 趈轉數の減 少, 壻加の兩方向に於て逆轉は起りにくい樣でせる。

次に逆轉の持續時間 (正轉が逆轉に變じ再び正轉に復する迄の時間) に就てみ上う。4 に於て述べた樣に觀察者, 圖形の種類, 又その時々によりかなり翼るのでせるが, 今觀察 者 $\mathrm{K}$ 圖形 $\mathrm{A}_{4}$ について比較してみよう。

0.33 では 1 秒 (約. 5 刻久) 前後のもの多く, 稀に 2 秒餘に達与るものがある。

0.6 では 1 秒乃至 1.5 秒つもの多く, 稀に 2 秒乃坌 2.5 秒に達するものがある。

1.1 ‘㤌 1 秒乃至 1.5 秒のもの多く, 時々 2 秒乃公 2.5 秒に達するものが女る。

1.3 では 1 秒乃至 2 秒のもの多く, 稀に 3 秒近いものが女る。

上記の樣に持續といふ點では迴轉數による差翼は餘り確然として居らない。

2）刻久の時間間隔：此法迴轉數に無關係に約 $\frac{1}{5}$ 秒であつた。（倘こ〉に使用した圖形

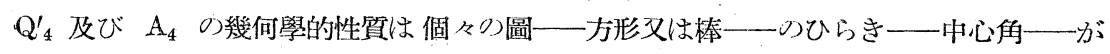
$90^{\circ}$ である點で類似してみるが，もてその點で異つた圖形を用ひたならばぞらであららか。 この點について充分實驗を試みる层をもたなかつたが，觀察者 $\mathrm{K}$ が圆形 $\mathrm{Q}_{2}$ で記錄した 
所によると，0.9 では約 $1 / 5$ 秒，1.3 では約 $1 / 5 \cdot 5$ 秒，1.5 では約 $1 / 5$ 秒を示してるる。從 つて圖琍の種類が異つても 1 刻久の時間は約 $1 / 5$ 秒だと云へやううこの刻みの時間間隔と 4 に於て述べた刻夕の距離間隔とから逆轉速度に遲速の女る事が解る。郎ち圖形が䁌員す ればする程逆轉速度は遲くなる。而して堌員は融合以前に於ては迴轉數の增加に件つて著 しくなる事は周知の通りであつて, 換言すれば迴轉數つ增加に伴つて逆轉速度は迤くなる。 こつ關係は本實驗の觀察に於て極めて明膫に觀取せられた。。更にこ〉に明記したいのは同 一條件下に於ける逆轉の速度がゲールケとラウが言つてるるる樣に必しも正轉の速度よりも 遲くない事である。例一ば圖形 $\mathrm{A}_{4} 0.3$ (現象的に 4 本の棒を見てるる時)に於ける逆轉 速度は每秒約 1.2 回轉で正轉速度の約 4 倍である。察するにゲールケとラウが逆轉は正 轉よりも遥が澱いと言つたのは, 例いば圖形 $\mathrm{A}_{4} 0.15$ に於ける樣に增員の程度の著しい 場合を指してるるむのと思はれる。

3) 逆轉生起の周期：持續觀察中には部分的には同一周期を以て現像してみることがわ かるが，周期時間は一定ではなく，觀察者に上り又その時くにより異つてるる。

7 別種又は刻みある逆轉の變形簡單に列記すれば次の通りである。

1) 總ての圖形に於て比較的低迴轉に於て圖が正轉寸るのと同時に見られる地の滑らか な而も極めて遲い逆轉。

2)總ての圖形，總てり迴轉數に於て見られる，圓形に照明せられた周邊部に現れる細 い三ヶ月形不等質部の滑らかな逆轉。(これは眼球の移動によるらしい)

3) 例へば圖形 $\mathrm{Q}_{4}$ に於て黑環生滅の際見られる極めて速い刻みのない逆轉, 或は圖形 $\mathrm{A}_{4}$ に於ける一僢全領域の白色化する際の速い滑らかな逆轉。

4) 方形圖形 $\left(\mathrm{Q}_{2,3,4}, \mathrm{Q}_{4}^{\prime}\right)$ 迫跡視の場合の凝視以外の方形の逆轉。(この場合追跡方形 と他の力形とは汽車がすれちがら樣に見える)

5）方形圖形追跡視の場合の凝視方形の自轉の逆轉。(この際には刻みが安る)

6）方形圖形追跡視の場合の凝視方形以外の方形の刻久安逆轉。(この際には 4 に於 ける樣にすれちがっ事はない)

(1939 年9月 16 日原稿受付)

1) Gehrcke und Lau: Versuche über das Sehen von Bewegungen Psychol. Forsch. 3 (1923) 2 